\title{
KENOSIS (SELF-LIMITATION OF GOD A Philosophical and Theological Approach
}

\author{
Hasan Özalp \\ Cumburiyet University, Sivas-Turkey
}

\begin{abstract}
The theistic concept of God is grounded in the absolute perfection of God. This belief has a philosophical and religious foundation. However, the idea of a perfect being also leads to various problems. Some philosophical and theological approaches attempt to solve such problems by limiting the attributes of God. Among them, kenosis offers solutions to certain difficulties in classical theism. However, it also creates additional issues. This study discusses the history of and problems associated with the limitation of God.
\end{abstract}

Key Words: Kenosis, self-limitation of God, omniscience, omnipotence, process philosophy, tzimtzum theory

\section{Introduction}

For a philosopher or theologian, the concept of God evokes several concepts and initiates discussions related to creativity, greatness, holiness, infinity, omniscience, omnipotence, and immutability. At a higher level, the focus is on the ontological and epistemological aspects of God, which are at the core of metaphysical discussions. Such discussions center on questions of how the metaphysical identity of God, as a transcendent being, can be comprehended within the ontological, epistemological, and linguistic limits of the physical world. How does God communicate and interact with nature, man, and history as an endless being with unlimited attributes? A simple analogy (with all its deficiencies) illustrates how this is possible: an adult who seeks to 
communicate with a child must simplify his perceptions and act to the child's level. This reduction is inevitable even though the interlocutors share the same ontological identity and mental and linguistic structure. Is God, who wants to communicate with man (a being with a different ontological, linguistic, and mental quality), and the universe (a separate substance), subject to certain restrictions when performing such an act? Although such issues are often considered theological, both metaphysics and hermeneutics address this problem. Discussions of the ontological and epistemological self-limitation of God rely on the concept of kenosis. The conceptualization of the term kenosis is concerned with establishing the identity of Jesus in the New Testament. Therefore, the issue is theological and represents a major problem of Christology. Nevertheless, the nature of God has been debated for centuries. Therefore, the general problem is establishing the content and functionality of the nature and attributes of God. This study seeks to explain the concept of kenosis - the limitation of God - and discuss the answers to questions resolved by or arising from the concept.

\section{Concept and History}

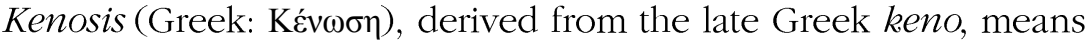
to empty something, to include nothing, and to be deprived of potency and puissance, objectivity, and essence. According to Christian theological doctrine, kenosis was the voluntary relinquishment by Jesus of divine attributes such as omniscience, omnipotence, and omnipresence to become a man. In the $19^{\text {th }}$ and $20^{\text {th }}$ centuries, Evangelical German theologians used kenotic Christology to justify and better comprehend incarnation. Later, Anglican and Russian Orthodox Churches accepted the concept. Paul's discussion of the nature and deeds of Jesus in the book of Philippians in the New Testament constitute the theological basis of kenosis. ${ }^{1}$

The first person to use the term "kenosis" was Theodotion $\left(2^{\text {nd }}\right.$ century AD), the Hellenistic thinker who translated the Hebrew Bible into Greek for the first time. Theodotion used the word as a theological term in his Greek translation of Isaiah" 34:11. ${ }^{2}$ However, Gregory of

C. Stephen Evans, "Introduction: Understanding Jesus the Christ as Human and Divine," in C. Stephen Evans (ed.), Exploring Kenotic Christology (The SelfEmptying of God) (Oxford \& New York, NY: Oxford University Press, 2006), 3-5; J. M. Carmody, "Kenosis," New Catholic Encyclopedia, Second Edition, (ed. Thomas Carson and Joann Cerrito; USA: Thomson Gale, 2003), VIII, 143.

All citations from the Bible are based on the New American Standard Bible, 
Nazianzus ( $4^{\text {th }}$ century) and Cyril of Alexandria ( $5^{\text {th }}$ century) employed this theological term to express the nature of Jesus as discussed in Philippians. In the Latin translation of the New Testament, kenosis corresponded with terms such as semetipsum exinanivit (self-emptying) and exbausit semetipsum (complete emptying), as seen in Tertullian's (160-225) Adversus Marcionem. ${ }^{3}$

Kenotic Christology, established in subsequent centuries through analyses of the New Testament, concentrates on the incarnation of Jesus. His incarnation indicates that he possesses two natures (hypostatic union), namely, divine and human. Is Jesus human or divine? If he is divine, why does he possess human attributes such as the ability to eat, drink, or die? If he is a God in the form of a man, then his attributes have been limited to those of a man. This question is addressed in Philippians 2:5-8 in the New Testament, which reads,

Have this attitude in yourselves which was also in Christ Jesus, who, although He existed in the form of God, did not regard equality with God a thing to be grasped, but emptied [kenosis] Himself, taking the form of a bond-servant, and being made in the likeness of men ...

In the text, Paul tells the Philippians in Macedonia that Jesus has a divine essence but that he relinquished his divine attributes to become an object to God. He eluded divine substance, albeit voluntary, and one who eludes divine substance has either eluded divine attributes as well or has limited himself with respect to these attributes. Today, the kenotic study of theology seeks to reconcile the nature of Jesus as a true historical divinity with his existence as an actual human being. ${ }^{5}$ In general theological terms, the problem is not that of a man (or Jesus) becoming God but the humanization of God - the positive and negative aspects associated with God's assumption of a limited human na-

updated 1995, https://www.biblegateway.com/versions/New-American-Standard -Bible-NASB (accessed April 10, 2014).

2 "But pelican (or owl or jackdaw) and hedgehog will possess it, and owl (or great horned owl) and raven will dwell in it; and He will stretch over it (Edom) the line of desolation (or formlessness) and the plumb (stones of void) line of emptiness."

3 Wayne E. Ward, "The Person of Christ: The Kenotic Theory," in Carl F. H. Henry (ed.), Basic Christian Doctrines (Dallas: C Bible Society, 2002), 132.

Philippians 2: 5-8.

5 Alva J. McClain, "The Doctrine of the Kenosis in Philippians 2:5-8," The Master's Seminary Journal 9/1 (1998), 86. 
ture. ${ }^{6}$ However, how can the passages of Holy Scripture ${ }^{7}$ that appear to favor creation out of nothing accord with kenotic theology?

A philosophical and theological approach similar to kenosis is the theory of tzimtzum, a concept proposed by the Kabbalistic school of Jewish mysticism. The theory explains the cosmic formation of the universe and cosmic history. According to some researchers, the cosmology of tzimtzum influenced kenotic doctrine. They suggest that the idea of creation in Christianity was constituted pursuant to tzimtzum. ${ }^{8}$

Lurianic Kabbalah, founded by Isaac ben Solomon Luria (15341572), has also developed a concept to explain the limitation of God. This approach, expressed by the theory of tzimtzum, explains how God created the universe and offers a way to balance God's transcendence and imminence. The tzimtzum theory seeks to answer the question, "if God is everything, how can He be a distinct being from the world?" In other words, if God is omnipresent and encompasses everything, where is the universe? Is God the universe? Is the universe God? In the context of the panentheistic mystical aspect of the Kabbalah doctrine, the concerns of Luria seem relevant. According this doctrine, God, who is divinely infinite (ein sof), has withdrawn (tzimtzum) to make space for beings other than Himself, leaving empty space. This process, called tzimtzum, began with creation. The divine emanation subsequently occurred in this space, and the formation of the cosmic system began. ${ }^{10}$

6 Oliver D. Crisp, Divinity and Humanity: The Incarnation Reconsidered (Cambridge: Cambridge University Press, 2007), 118. According to Crisp, kenosis has two forms: ontological and functional. However, because he focuses on the debate about incarnation, particulars will not be described here. Kenotic Christology treats the nature of God, while kenotic theology discusses the possibility of Jesus' divinity.

7 For discussions of the incarnation of Jesus and creation out of nothing, see Simon Oliver, "Trinity, Motion and Creation ex Nihilo," in David B. Burrell, Carlo Cogliati, Janet M. Soskice, and William R. Stoeger (eds.), Creation and the God of Abraham (Cambridge: Cambridge University Press, 2010), 133-151.

8 Manuel G. Doncel, S. J., "The Kenosis of the Creator and of the Created CoCreator," Zygon 39/4 (2004), 792; Jürgen Moltmann, God in Creation: An Ecological Doctrine of Creation (The Gifford Lectures 1984-1985) (London: SCM Press, 1985), 87.

9 Ali Osman Kurt, Ultra-Ortodoks Yabudiler: Hasidiler ve Mitnagedler (Sivas: Asitan Yayinlar1, 2011), 223.

10 See Pinchas Giller, Reading the Zohar: The Sacred Text of the Kabbalab (New 
The fundamental elements of the cosmology of tzimtzum include i) God created empty space to limit His essence and create; ii) God withdrew into Himself for Himself; and iii) God remained God. ${ }^{11}$

As scholars have noted, God first limits Himself or His power, after which the creation (or cosmic becoming) occurs. Tzimtzum is this ontological self-limitation of God. ${ }^{12}$ By means of this theory, Solomon Luria both manifests the transcendence of God and claims that the universe is a distinct substance from God. Tzimtzum also offers a new theodicy, stating that the source of evil in the world is independent from God. In addition, Luria rejects the concept of the eternal knowledge of God, creating the possibility of an unknown future and a range of possibilities for action in the world. According to Moltmann, the tzimtzum theory encompasses all models about the limitation of God. ${ }^{13}$

The Lurianic theory of becoming bears certain similarities to the Neo-Platonist theory of cosmic emanation. Both theories describe the cosmic formation using the term "emanation." The limitation of God within Neo-Platonist emanation theory will be treated later in this paper.

In the modern era, a group of theologians, philosophers, and scientists led by Alfred North Whitehead (1861-1947) and Charles Hartshorne (1897-2000) developed process theology, which favors the ontological and epistemological limitation of God. The issue of limitation is an important component of process philosophy, which attempts to construct the relation between God, nature, and man via the dualistic nature and knowledge of God. This construction has made a notable contribution to the modern theology of nature. However, Javier

York, NY: Oxford University Press, 2001), 70-82; Joseph Dan, Kabbalab: A Very Short Introduction (New York, NY: Oxford University Press, 2006), 74-75; Kurt, Ultra-Ortodoks Yabudiler, 223.

11 Moltmann, God in Creation, 86-89; Alan J. Torrance, "Creatio ex Nibilo and the Spatio-Temporal Dimensions, with special reference to Jürgen Moltmann and D. C. Williams," in Colin E. Gunton (ed.), The Doctrine of Creation: Essays in Dogmatics, History and Philosophy (London \& New York, NY: T \& T Clark, 2004), 89.

12 Rav Michael Laitman, Basic Concepts in Kabbalab: Expanding Your Inner Vision (Toronto, Ont.: Laitman Kabbalah Publishers, 2006), 99; Kurt, Ultra-Ortodoks Yabudiler, 224.

13 Robert John Russell, "Introduction," in Robert John Russell, Nancey Murphy and Arthur R. Peacocke (eds.), Chaos and Complexity: Scientific Perspectives on Divine Action (Vatican City State: Vatican Observatory Publications, 1995), 24. 
Monserrat, who studies kenosis and the relationship between God and nature, does not consider kenotic theology to be an interpretation of process philosophy and theology. ${ }^{14}$ This argument led to a debate about the relationship between the concept of the trinity and natural theology. Process philosophy's approach to the issue will be addressed in other sections. In the present article, the problematic aspect of kenosis will be addressed and the relevant ontological limitation of God's omnipotence and omniscience will be discussed.

\section{Kenosis as Problematic}

Since ancient times, almost every monotheist religion has professed a common conception of God as eternal, infinite, omniscient, omnipotent, omnipresent, having an immutable nature, and a perfect and absolute being. ${ }^{15}$ Lurianic thought differs from theism because it establishes equality between transcendence and imminence, whereas kenotic Christology departs from the dual nature of Jesus to distinguish the divine from the human and natural and to reconcile the two despite this distinction. Considering that kenotic theology appeared as late as the $19^{\text {th }}$ and $20^{\text {th }}$ centuries, it evidently takes a different approach than tzimtzum theory and Christology. Kenotic theology focuses neither on the Jesus' becoming God nor on the humanization of God. In the words of Swinburne, kenotic Christology does not consider science and potency as part of the essence of God. ${ }^{16}$ Therefore, the understanding of God in classical theism does not completely satisfy kenotic theologians. For which problems, then, does kenosis offer a solution? What are its philosophical and theological justifications?

As science, historical analyses, and New Testament research pro-

14 Javier Monserrat, "Kenosis: Towards a New Theology of Science," Pensamiento: Revista de investigación e Información filosófica 63/238 (2007), 639. Monserrat attempts to construct a new scientific theology to establish the relationship between religion and science in the modern era.

15 See Edward R. Wierenga, The Nature of God: An Inquiry into Divine Attributes (Ithaca, NY: Cornell University Press, 1989); Mark Owen Webb, "Perfect Being Theology," in Charles Taliaferro, Paul Draper, and Philip L. Quinn (eds.), A Companion to Philosophy of Religion ( $2^{\text {nd }}$ edn., Malden, MA: Wiley-Blackwell, 2010), 227-234; Richard Swinburne, The Coherence of Theism (revised edn., Oxford: Clarendon Press, 1993), 99-124; Recep Alpyağıl (ed.), Gelen-eksel ve Çağdas Metinlerle Din Felsefesine Dair Okumalar 1 (Istanbul: İz Yayınc1l1k, 2011), 611739.

16 Swinburne, The Christian God(Oxford: Clarendon Press, 1994), 230. 
gressed in the $19^{\text {th }}$ century, the nature of Jesus again became a subject of debate. The Graf-Wellhausen school and radical Tübingen school defended the Old Testament and New Testament, respectively, against evolutionary theory's criticisms and argued for the doctrine founded on the divine and unique nature of Jesus. ${ }^{17}$ Therefore, in the $19^{\text {th }}$ and $20^{\text {th }}$ centuries, as humanism and the natural sciences became dominant, kenotic theology was sustained by kenotic Christology and by certain common points of departure from tzimtzum cosmology that ascribed the limited attributes of man to God to limit the latter.

The God-nature and God-man relationships reflect the main concerns of kenotic theology, which concentrates on the following issues: i) The potency and nature of God (if God created the universe Himself and imposed the laws that ensure its operation, man will always need God to orchestrate these processes). ii) The knowledge of God and man (if God has infinite knowledge, man cannot have free will). iii) The necessity of the ontological and epistemological limitation of God.

Therefore, the primary objective of kenotic theology is to limit the potency of God and provide nature with autonomy so that it can act independently from God. This approach limits God in spatial terms by limiting his potency, pushing Him out of nature and thereby enabling science and scientific research. The second limitation is temporal and limits the knowledge of God to make man a free agent. Such limitation requires the exclusion of God from the present and future acts of man. All of these limitations eventually restrict the nature of God.

\section{The Nature of God and Its Ontological Limitations}

Lurianic Kabbalah's tzimtzum theory, kenotic theology, and process philosophy are based on the ontological limitation of God. Monserrat claims that his new scientific theology is independent of process philosophy; nevertheless, his understanding of God prescribes the limitation of God as a substance. The ways in which tzimtzum theory and kenotic Christology restrict God as substance were discussed above. Despite being introduced as a new line of thought, process theology philosophically relies on tzimtzum theory and kenotic theology. Indeed, process theology remarkably resembles the image of God developed by Descartes (1596-1650) and Spinoza (1632-1677) in their theories of substance. The crystallization of this influence is apparent in the relation established by Spinoza between "nature naturing" (natura

17 Ward, "The Person of Christ: The Kenotic Theory," 132. 
naturans) and "nature natured" (natura naturata). As Arican indicates, God is both absolute substance and nature, or creative nature. ${ }^{18}$ Arıcan's statement, "everything is within God," incorporates Spinoza into the group of panentheist philosophers to which Whitehead also belongs. ${ }^{19}$

The present chapter will primarily analyze the ways in which God is understood in kenosis and in process philosophy, which have similar philosophical backgrounds. The concept of God in process theology will be briefly discussed, as will the relation between its premises and the understanding of God in classic theism. The possibility of the ontological limitation of the concept of God in classic theism will also be explored.

The fundamental motive of process philosophers is to advance the modern natural sciences. During the transition from Newtonian physics to Einstein's theory of relativity and quantum mechanics, the universe abandoned its solid matter status for a changing and metamorphosing structure. As Muhammad Iqbal (1877-1938) indicates, in the premodern era, the universe was conceived as a machine, while it is now considered an organism. ${ }^{20}$ Therefore, the perception that God created the universe from a single substance is insufficient to explain the dynamic structure of the universe. To address this issue, Whitehead developed a new concept of God that emphasized such deficiencies and inconsistencies, especially those related to the idea of absolute substance. In particular, the excessive emphasis on the metaphysical and the idea that substance excludes religious experience led Whitehead towards a new conception of God. Thus, giving nature autonomy, he attempted to solve the problem of free will.

Convinced of the insufficiency of traditional cosmic systems, Whitehead attempts to establish a new system. According to him, Aristotle's (384-322 BC) Prime Mover is a being with certain attributes that make it a logically necessary component of Aristotle's cosmic system. The Aristotelian Prime Mover had an initially voluntary and later compulsory

18 M. Kazım Arıcan, Panteizm, Ateizm ve Panenteizm Bağlammda Spinoza'mın Tanrı Anlayışı (Istanbul: İz Yayıncılık, 2004), 71-72.

19 Ibid., 166.

20 See Muhammed İkbal (= Muhammad Iqbal), İslâm'da Dinî Düşüncenin Yeniden Doğuşu (translated into Turkish by N. Ahmet Asrar; Istanbul: Birleşik Yayıncılık, n.d.), 54-71. 
influence on Judaism and Islam before influencing Christianity. ${ }^{21}$ Iqbal, agreeing with Whitehead, notes that the early Muslim Kalam scholars "read the Qur'ān under the light of Greek thought, and could comprehend - albeit not completely - that the essence of the Qur'ān was in opposition with classic ideas only 200 years later."22 The later medieval and modern philosophers ascribed certain metaphysical qualities (such as simplicity, immutability, etc.) to the Aristotelian Prime Mover to imbue it with a special capacity; they attributed to the Prime Mover absolute transcendence and conceived it as an imaginary and deceptive element that preceded the world. ${ }^{23}$ If metaphysics were to be built upon physics, the Aristotelian physical and cosmic system would have to be rejected; it is now considered incorrect. ${ }^{24}$

Whitehead develops a cosmic theology of his own -natural theology- to overcome such problems and establish a new cosmology. ${ }^{25}$ The nature of God constitutes the core of his theology. According to Whitehead, God has a dipolar nature, one pole constant and other variable. This structure, which Whitehead calls Primordial Nature, corresponds to the immutable character of God. ${ }^{26}$ Consequent Nature is the aspect of nature that is realized and that realizes itself within nature. This dimension of God is involved in the process of development and change; it changes with nature. The realization of the consequent nature of God and its relationship with nature has three purposes: to ensure i) an infinite conceptual realization; ii) the multiple solidarity of free physical realizations within the temporal world; and iii) the ultimate union between the multiplicity of actual reality and conceptual primordial reality. This nature, which is present in physical processes, is the energy of physical development. It does not merely create the universe, but protects it. This nature is the source of order and the poet

21 Alfred North Whitehead, Science and the Modern World (New York, NY: New American Library, 1948), 173.

22 İkbal, İslâm'da Din̂ิ Düşüncenin Yeniden Doğuşu, 20. For the influence of Whitehead on Iqbal, see Mevlüt Albayrak, "Muhammed İkbal'in Din Felsefesinde Alfred North Whitehead'in Etkisi," Dinî Araştırmalar4/11 (2001), 35-65.

23 Whitehead, Science and the Modern World, 179; Mehmet S. Aydın, "Süreç (Proses) Felsefesi Issığında Tanrı-Âlem İlişkisi,” in his Âlemden Allab'a (Istanbul: Ufuk Kitaplar1, 2001), 61.

24 Whitehead, Science and the Modern World, 174.

25 Whitehead's work is entitled Process and Reality: An Essay in Cosmology.

26 Whitehead, Process and Reality: An Essay in Cosmology (New York: The Free Press, 1978), 342-347. 
that leads the universe with patience. ${ }^{27}$

As Whitehead and other researchers suggest, God is a limited concept in ontological terms and with respect to knowledge and poten$\mathrm{cy}^{28}$ Specifically, the consequent nature of God has almost nothing in common with the immutable, simple God of classical theism.

The theistic concept of the nature of God is generally based on holy writ, human experience, and philosophical investigation. All theistic religious faiths consider God to be a perfect being. ${ }^{29}$ According to this belief, God is not limited; He has the attributes of simplicity, incorporeality, immutability, and impassibility. All of these attributes correspond to the substance that reflects the perfection of God. Whitehead's God, however, possesses a dipolar constitution. In this respect, his theory is contrary to both the simplicity and immutability of God. Moreover, Whitehead reduces God to a passive being under the influence of nature.

Whitehead's revision is based on the following question: If God had an immutable and absolute nature, how would He interact with nature? Whitehead answers this question by ascribing a dipolar character to God. However, God's simple substance and thus immutable nature, or, as Whitehead criticizes, His single substance, does not prevent Him from interacting with nature. For example, several Qurānic"verses, including "I have created with my hands" My spirit,"31 point out the imminent character of God in direct relation with the universe. Other passages, such as "He begetteth not, nor is $\mathrm{He}$ begotten, and there is none like unto Him"32 and "there is nothing whatever like unto Him," ${ }^{33}$ stress His transcendence as a substance distinct from nature. Therefore, God can be both transcendent and imminent in the same substance, indicating that He is active in different states. Although Whitehead ascribes to God a consequent nature to

\footnotetext{
Whitehead, Process and Reality, 347; John B. Cobb, Jr. and David R. Griffin, Süreç Teolojisi (translated into Turkish by Tuncay İmamoğlu and Ruhattin Yazoğlu; Istanbul: İz Yayıncilık, 2006), 72-73.

28 See Aydın, "Süreç (Proses) Felsefesi Işığında Tanrı-Âlem İlişkisi," 68.

29 Wierenga, The Nature of God, 1-5; Webb, "Perfect Being Theology," 227.

" All citations from the Qur'ān are based on the translation into English by Abdullah Yusuf Ali.

30 Q 38:75.

31 Q 15:29; 38:72.

32 Q 112:3-4.

$33 \mathrm{Q}$ 42:11.
} 
emphasize the natural sciences and the imminence of God, he cannot avoid also ascribing to God the character of a constant substance, as in classical theism.

This limitation creates an additional problem about the simplicity and immutability of God. First, the simplicity of God (He is not composite) does not allow for His disintegration, and in this He differs from the material universe. Simplicity necessarily requires a thing to be single $^{34}$ and immutable. The nature of God, however, comprises two changes: God either expands (or advances) or contracts (as in tzimtzum). Both are impossible, or at least controversial, if God's substance is simple. This substance does not consist of parts; God does not have accidental features, and a distinction cannot be made between His content and form..$^{35}$ Because the substance of God is simple, He is immune to change and therefore cannot be incorporated within categories of time and space. As discussed above, this characteristic of God is the most apparent attribute that distinguishes Him from those He creates/brings into being. Since Thales, most Eastern and Western philosophies and theologies have agreed on this issue of immutability. ${ }^{36}$ However, if the substance of God undergoes any change whatsoever (horizontal/expansion or vertical/advance), then God becomes imperfect. Similarly, if God's substance contracts, why does God reduce and degrade Himself to a lower category? Multiple verses in the Hebrew Bible, including "I am who I am," ${ }^{37}$ "but You are the same, and Your years will not come to an end," 38 and "Jesus Christ is the same yesterday and today and forever" ${ }^{39}$ emphasize His immutable nature. Addi-

34 Robin Le Poidevin, "Kenosis, Necessity and Incarnation," The Heythrop Journal 54/2 (2013), 216; Alvin Plantinga, Does God Have a Nature? (Milwaukee, WI: Marquette University Press, 1980), 28, 30.

35 Michael J. Dodds, The Unchanging God of Love: Thomas Aquinas and Contemporary Theology on Divine Immutability ( $2^{\text {nd }}$ edn., Washington, D.C.: The Catholic University of America Press, 2008), 134-161; Eleonore Stump, "Simplicity," in Charles Taliaferro, Paul Draper, and Philip L. Quinn (eds.), A Companion to Philosophy of Religion ( $2^{\text {nd }}$ edn., Malden, MA: Wiley-Blackwell, 2010), 270.

36 See İsmail Erdoğan, "Tanrı'nın Değişmezliği Problemi," Uludağ Üniversitesi İlabiyat Fakültesi Dergisi 13/1 (2004), 39-52; Richard E. Creel, "Immutability and Impassibility," in Charles Taliaferro, Paul Draper, and Philip L. Quinn (eds.), A Companion to Philosophy of Religion ( $2^{\text {nd }}$ edn., Malden, MA: Wiley-Blackwell, 2010), 322-323.

37 Exodus 3:14.

38 Psalms 102:27.

39 Hebrews 13:8. 
tional expressions of approval and reiteration in the Qurān, such as "Verily, I am Allah" ${ }^{40}$ stress the immutable nature of God and His independence from time and space.

One might ask, "Does God have the will and freedom to expand and contract His own substance?" Such a question ignores that the debate focuses not on God's attributes, but His substance. Therefore, the question is moot; God, in an ontological sense, is God because He has an immutable substance.

Like all other philosophers and theologians, Whitehead explores how the relation between being and becoming is established and which of the two is dominant. To explain becoming, Whitehead limits and reduces being both ontologically and epistemologically. This strategy both provides the law of nature with autonomy and allows man to act freely. However, in the process, God becomes free from holiness, according to kenotic Christology, and is humanized.

\section{Limitations in the Relation between God and Nature: Omnipotence}

According to classical theism, God's omnipotence indicates that $\mathrm{He}$ has endless and unlimited power and ability to act. Therefore, the omnipotence of God complements His attribute of knowledge / omniscience ( $\mathrm{c}$ lm). In other words, if God were omniscient but not omnipotent, this would create a deficiency and inconsistency. The same insufficiency would appear if He were omnipotent but not omniscient. Therefore, knowledge and potency are not entirely independent attributes of God. Potency actually means to create and maintain that which is created by orchestrating and coordinating it through knowledge.

There are several reasons to limit God's potency. First, His endless power leads to the perception of a God who is a despot. Second, such limitation decreases God's absolute intervention in the universe and creates space for the natural sciences. Al-Ghazālī (1058-1111), for example, rejected causality to defend the limitlessness of potency, claiming, "it is not the fire, but either Allah in person or, through His mediation, the angels, who burn the cotton."11 Therefore, the dismissal of

\footnotetext{
Q 20:14.
}

41 Abū Ḥāmid Muḥammad ibn Muhammad al-Ghazālī, Filozoflarn Tutarsızlı̆ $ı$ (Tahāfut al-falāsifa) (ed. with Turkish translation by Mahmut Kaya and Hüseyin Sarıoğlu; Istanbul: Klasik Yayınları, 2005), 166-167. 
causality not only restricts but abolishes science's freedom of movement. Third, this view ironically provides God with a more active role in universe. The transcendent God of classical theism is conceived of as distant from the universe. In process philosophy, however, the consequent nature of God coexists with the universe. This approach renders God more active in nature. This again raises the question of the place of science and scientific laws in a nature in which God actively exists. The limitation problem appears at this juncture because in the course of creating the universe, God also creates Himself. Specifically, the consequent nature of God knows and creates during the formation of the universe. Fourth, the problem of evil must be resolved. If God does not know and does not create the universe (due to His limited potency), the evil in the universe occurs independently from God. Therefore, God cannot be held responsible for evil. Next, I will demonstrate how potency is limited.

According to tzimtzum theory, God withdraws Himself and creates a space in which the universe can come into existence. Consequently, the universe is a form independent from God because it consists of the space from which God has withdrawn. Therefore, neither the universe that comes into existence in this space nor any deficiency and evil in this universe can be associated with God. Tzimtzum theory therefore implicitly and indirectly limits God.

Pursuant to the doctrine of kenotic Christology, once God voluntarily renounces his divine qualities and assumes a human identity, He simultaneously relinquishes attributes that express His perfection, such as knowledge and potency. This is a limitation and it is God, who is the being subject to these limitations.

The most systematic conceptualization of the limitation of the potency of God is found in process philosophy. The central thesis of process philosophy concerns primordial and consequent, or divine and earthly, elements. ${ }^{42}$ The divine (primordial) corresponds to the immutable nature of God, while the earthly and actual reflects His changing nature. Hence, God has a metaphysical nature in one sense and physical nature in another. God, therefore, exists in relation to the physical world. Creation is clearly the most fundamental concept used to explain this relation. Whitehead and Hartshorne both accept the idea of creation. To them, however, creation does not mean to create some-

42 See Rem B. Edwards, "God and Process," in James Franklin Harris (ed.), Logic, God and Metaphysics (Dordrecht: Springer Netherlands, 1982), 41. 
thing out of nothing in the classical sense. According to Hartshorne, creation means to determine the undetermined, to assign the unassigned and thus to contribute to the richness of reality. ${ }^{43}$ In other words, creation produces something new and is the particular determination of each act by the being actualized through the experience. ${ }^{44}$ Hartshorne considers creation not as empirical knowledge but as an experience that occurs within itself. For him, creation occurs throughout the universe. Specifically, everyone and everything is a creator of his or its respective form of becoming: to be is to create. ${ }^{45}$ As noted earlier, creation is the formation of the consequent aspect of God, the universe and the self-generation of beings through simultaneous processes. This conceptualization of creation also reflects how process philosophy understands causality.

Iqbal, who envisages limitations to creation, makes, like Hartshorne, a deduction between experience and actuality. Iqbal says, "universe is a free creative act, in view of the similarity of our conscious experiences." ${ }^{\prime 6}$ According to Iqbal, nature is not a mechanical structure. ${ }^{47}$ For him, "nature is a living, ever developing organism with no outward boundary against its growth and expansion. Its only limit is within (italic belongs to us). That is, the One who animates and feeds the whole is the ubiquitous Person." ${ }^{18}$ Consequently, Iqbal, who begins with the knowledge of Allah, eventually advances to His potency; he limits God's knowledge and potency to allow the continuous selfactualization of nature and to maintain the meaning and continuity of its dynamism.

No doubt, the emergence of egos endowed with the power of spontaneous and hence unforeseeable action is, in a sense, a limitation on the

\footnotetext{
Aydın, "Süreç (Proses) Felsefesi Işı̆̆ında Tanrı-Âlem İlişkisi," 89.

44 Santiago Sia, God in Process Thought: A Study in Charles Hartshorne's Concept of God (Dordrecht \& Boston: Martinus Nijhoff Publishers, 1985), 73.

45 Ibid., 74.

46 İkbal, İslâm'da Dinî Düşüncenin Yeniden Doğuşu, 77.

47 Notably, Iqbal cites modern physics and biology data on the topic.

48 İkbal, ibid., 84. Polkinghorne states the following about how nature abandoned a mechanical structure to become a living organism: if nature is an organism, God is naturally the soul of this world (John Polkinghorne, Faith, Science \& Understanding [New Haven, CT: Yale University Press, 2000], 107). Pursuant to such a deduction, if nature has a soul, as Polkinghorne says, this soul belongs to God. This view leads to the consequent nature of panentheism, in which God instils life in nature but is also formed by it.
} 
freedom of the all-inclusive Ego. But this limitation is not externally imposed. It is born out of His own creative freedom whereby He has chosen finite egos to be participators of His life, power, and freedom. ${ }^{49}$

Iqbal is aware that such limitation requires the denial of an advanced level of potency, and he explores this problem. For Iqbal, the Qur'ān does not relish abstract rules; moreover, modern philosophy has yet to apprehend relativity. ${ }^{50}$ According to Iqbal, the potency of abstract concepts is a blind, uncontrolled power reminiscent of tyranny. ${ }^{51}$ Consequently, he discusses evil ${ }^{52}$ and the freedom of $\mathrm{man}^{53}$ in his search for the solution to the abovementioned problems. Likewise, Hartshorne argues that God saves Himself from tyranny by allowing the formation of free beings. ${ }^{54}$

Scholars such as Aydin, C. A. Kadir and M. S. Raschid argue that Iqbal restricts God, but Nached Qutab rejects Iqbal's concept of "limited". ${ }^{55}$ According to process philosophy, God's primary nature is unlimited, but His secondary nature is limited. God's character, for Iqbal, is not entirely balanced; however, God is unlimited in terms of acting with nature and knowing each of His actions, and it is evident that the acts and knowledge of God are actualized at the moment of becoming. ${ }^{56}$ Iqbal appears to restrict God for a reason. He clearly expresses limitation; therefore, any contradictory statement requires an explanation beyond a literal interpretation. God is explicitly restricted regardless of content and character.

49 İkbal, ibid., 112.

50 Today, philosophy understands and has moved beyond the theory of relativity. The present challenge is to explain being and becoming via quantum physics. In quantum philosophy, God knows every past and future possibility and knows the future as a determined future.

51 Charles Hartshorne, A Natural Theology for Our Time (6 $6^{\text {th }}$ edn., La Salle, III: Open Court, 1989), 119; İkbal, ibid., 112-113.

52 İkbal, ibid., 113.

53 Ibid., 120.

54 Charles Hartshorne, Omnipotence and Other Theological Mistakes (Albany, NY: State University of New York Press, 1984), 69.

55 Aydın, "Süreç (Proses) Felsefesi Işı̆̆ında Tanrı-Âlem İlişkisi," 98 ff.; id., "Muhammed İkbal'in Din Felsefesinde 'Ulûhiyet' Kavramı," Ankara Üniversitesi İlâhiyat Fakültesi İslâm İlimleri Enstitüsü Dergisi 4 (1980), 208.

56 Mehmet S. Aydın, "Muhammed İkbal'in Din Felsefesinde 'Ulûhiyet' Kavramı," 209. 
Is it impossible, then, to restrict God in any manner? The "paradox of the stone" (omnipotence paradox) is a striking example of the inherent contradiction between God and His potency:

(i) God either can or cannot create a stone that He may not lift.

(ii) If God creates a stone so beavy that He cannot lift it, He is not omnipotent.

(iii) If God cannot create a stone so beavy that He cannot lift it, then He is not omnipotent.

(iv) Therefore, God is not omnipotent. ${ }^{57}$

In this example, God is either unable to create such a stone or cannot lift the stone He created. In any case, the outcome indicates that He lacks infinite power. A theist cannot reply in the affirmative to the question "Can God create a stone bigger than Him?" because it is impossible to imagine something greater than God. Numerous similar examples could be cited. When God creates by selecting one among the endless possibilities within His infinite knowledge, is that not an indication of limitation? There are other paradoxical questions that challenge the omnipotence of God, such as whether God can create a circle in the form of a square without deteriorating the latter, make $2+2$ equal 5, change the past, kill Himself, fit the world into something the size of an egg, and hold man in both a sitting and standing position. ${ }^{58}$

Theology generally considers creation as the free act of God executed through His reason and will. In other words, the universe was not formed unconsciously but by the will of God. ${ }^{59}$ Given the attributes shared by God and man, the abovementioned problems can be viewed in two ways. In the first, the facts contradict logic and potency. In the second, the facts comply with logic but contradict potency. The first perspective addresses whether God acts according to his potency, but acts illogically. Such a suggestion propels God into the realm of absurdism. For example, if God has the power to make $2+2$ equal 5 , and He does so, then God is potent but unreasonable. In this example, God

57 Wierenga, The Nature of God, 31-32.

58 Eric Lee Ormsby, İslam Düşüncesinde 'Tlabi Adalet' Sorunu (Teodise) [= Theodicy in Islamic Thought: The Dispute Over Al-Ghazali's Best of All Possible ] (translated into Turkish by Metin Özdemir; Ankara: Kitâbiyât, 2001), 156; Harry Austryn Wolfson, The Philosophy of the Kalam (Cambridge, Mass. \& London: Harvard University Press, 1976), 585.

59 Keith Ward, Rational Theology and the Creativity of God (Oxford: Basil Blackwell, 1985), 73-74. 
contradicts Himself; a premise that is illogical for man is also illogical for God. The question of God's ability to commit suicide is resolved by a similar approach. In this approach, which Ibn Hazm called absolutely impossible, God is no more a simple substance and therefore no longer possesses the quality of God. ${ }^{60}$ The problem is one of logic, not potency. God is God because He does not die. According to al-Ghazālī, the field of potency cannot include something impossible; therefore, a thing that is established as a condition without being a condition cannot exist. ${ }^{61}$ The falsity of the premise arises from the breach of the Aristotelian principle of non-contradiction; an illogical premise cannot be made reasonable by adding God to the beginning. ${ }^{62}$ Therefore, if the potency does not produce something illogical, this does not indicate limited power.

The second problem addresses God's conformity with logic but not potency. The most typical example of this is the creation itself. God's choice to create one thing among the infinite unlimited possibilities restricts Him. His potency is restricted by existence, but it cannot be used to limit Himself. ${ }^{63}$ For example, Thomas Aquinas (1225-1274) argues that God cannot breach the law of time when discussing a case in which "God restores a woman, who has lost her virginity, to her previous condition." He concludes, "God may forgive the sin of that person, and restore her bodily chastity through miracle, but cannot make something, which has already happened, not happened." ${ }^{164}$

God created the universe, one of many possibilities (man was also one of the possible alternatives) and thus restricted His potency. However, this does not indicate the limitedness of His knowledge and potency. Knowledge and potency are limited, but God created a form (the universe) by His free universal will. This paper does not subscribe to the "possible worlds" theory of al-Ghazāli and Leibniz (1646-1716). ${ }^{65}$ God could have created the universe in a far superior form and He

\footnotetext{
60 Wolfson, The Philosophy of the Kalam, 585-586.

61 Al-Ghazālī, İtikadda Orta Yol (al-Iqtișād fì l-i'tiqād) (ed. with Turkish translation by Osman Demir; Istanbul: Klasik Yayınları, 2012), 91.

62 Richard Swinburne, Tanm Var mı? (translated into Turkish by Muhsin Akbaş; Bursa: Arasta Yayınlar1, 2001), 6 ff.; Mehmet S. Aydın, Din Felsefesi $\left(10^{\text {th }}\right.$ edn., Izmir: İzmir İlâhiyat Fakültesi Vakf1 Yayınları, 2002), 148-149.

63 Keith Ward, Rational Theology and the Creativity of God, 84-85.

64 Umberto Eco, Yorum ve Aşı Yorum (translated into Turkish by Kemal Atakay; $4^{\text {th }}$ edn., Istanbul: Can Yayınlar1, 2008), 42.

65 For further discussion, see Ormsby, ibid., 139-215.
} 
could have brought man into being in a far superior form. However, God chose this form among all possible forms. This fact may seem to indicate the limitedness of potency; however, it is an indicator of the limitlessness of His will. Once God created the universe in its present form, He created man in a form suitable to live in the universe. With His potency, He could have created man in a more superior form within the limits of the universe. However, His knowledge restricted His potency in an exercise of wisdom. ${ }^{66}$ Though God has endless potency and knowledge, this does not make Him a tyrant. His knowledge and other attributes, such as mercy, control His potency. "Control" does not mean "limit" in the sense of "reduce;" instead, this term indicates that God's attribute of potency acts in compliance with attributes such as knowledge, mercy, justice, etc.

God's creation of the universe in a given form shows the independence of His will, not the limitedness of His power. This fact also disproves Keith Ward's argument that God has a simple substance and is therefore necessary and has no freedom of choice during the act of creation. ${ }^{67}$ The idea of a necessary being refers not to an ontological but to a logical necessity. In addition, even if an ontological necessity were in question, this would establish the existential, not the actual, necessity of God.

The idea of a self-sacrificing God who limits Himself to provide nature with autonomy and set man free solves several philosophical and theological problems. However, this view also raises additional philosophical and theological questions. Within this system, God is not active but only seems active. A God who is creative but not active approximates the deistic concept of God. It may be more accurate to describe this hidden God (deus absconditus) - who limits Himself while providing the world with autonomy to conduct scientific research - as a quiet, calm master of the cosmos.

\section{Limitation of the Relation between God and Man: Omniscience}

God's knowledge is one of the principal problems of philosophy and theology. The problem centers on questions of what, how, and how much God can know. Classical theism perceives the knowledge

\footnotetext{
66 This paper accepts the anthropic principle, or the synchronization between man and universe, as a theological reality.

67 Keith Ward, ibid., 73-75.
} 
of God as determinist knowledge, meaning that God knows and understands everything that will happen in the future. The indeterminist approach restricts the knowledge of God through certain philosophical and theological considerations. ${ }^{68}$ According to the determinist approach, God's omniscience and essential perfection allow Him to know everything; omniscience means to possess an eternal knowledge of all. This definition indicates the essence and perfection of God and emphasizes that God knows all. God's infinite provides us with insight into what He knows. The omniscience of God has temporal and spatial dimensions. Temporally, God simultaneously knows the entire past, present and future. Spatially, God possesses knowledge about man, nature and history throughout time. God therefore knows everything except Himself, independent of temporal and spatial conditions and limitations. A perfect being has impeccable knowledge. ${ }^{69}$

The perfection of divine science creates two problems. First, God, who has a simple substance, has the ability to change because He has knowledge about change. Second, free will is challenged. Free will is an issue, not because God knows past and present, but because He knows the future, or what is yet to happen. If God knows that which is to come, then the choices and actions of man are known in advance. ${ }^{70}$ This foreknowledge is also final knowledge of a fact, making man the puppet of a prescribed fate and giving rise to the problem of free will, often debated in the fields of theology and philosophy. Indeed, such discussions are relevant because the philosophies and theologies that stipulate the limitation of God are based on such concerns. Below, the theological debates about the limitation of God's knowledge are summarized.

The statement that "the knowledge of God changes when the subject of the knowledge changes" can be explained in two ways. According to the first explanation, God knows the universal; the second explanation is based on the limitation of the knowledge of God. According to Aristotle, God, who is the Prime Mover, cannot think about anything but Himself because of the simplicity of His substance. Because

68 See Metin Özdemir, Allab'in Bilgisinin Ezelîliği ve İnsan Hürriyeti (Istanbul: İz Yayınc1lik, 2003), 29.

69 For further discussions, see George I. Mavrodes, "Omniscience," in Charles Taliaferro, Paul Draper, and Philip L. Quinn (eds.), A Companion to Philosophy of Religion (2 ${ }^{\text {nd }}$ edn., Malden, MA: Wiley-Blackwell, 2010), 254-255.

70 Hartshorne, Omnipotence and Other Theological Mistakes, 26; Mavrodes, "Omniscience," 255. 
everything other than God is composite, or subject to change, if God had knowledge of something ever-changing, his knowledge would change. Therefore, God only thinks about and knows Himself. $^{71}$ Hence, Aristotle restricts God, and Peripatetic tradition has abided by the Aristotelian conception of God. Although the words of Aydin are subject to interpretation, he suggests that the God of Plotinus is not a being who knows in the theistic sense. ${ }^{72}$ The Peripatetic Muslim philosophers, including Alfarabi (872-950) and Avicenna (980-1037), systematically extended and maintained this tradition but took a different approach to the knowledge of God. According to Avicenna, God knows all; nothing can be hidden from Him. However, God knows the particular in a universal manner. ${ }^{73}$ In discussions of "God's lack of knowledge on particulars," al-Ghazālī declares Avicenna an unbeliever for restricting the knowledge of Allah. ${ }^{74}$ As Averroes (1126-1198) indicates, categories such as universal and particular belong to man and allow him to better understand existence. For God, however, such classifications are impossible. Therefore, the knowledge of God is universal and encompasses the particular. ${ }^{75}$

Arguments about substance, such as "if the knowledge of God changes, then He also changes," do not seem sufficiently consistent. According to Averroes, the assertion that God undergoes a change when a particular changes is incorrect because it is the particulars (objects, facts, etc.) that change, not God. ${ }^{76}$ Avicenna's thesis of universal

71 Aristotle, Metafizik (translated into Turkish by Ahmet Arslan; Istanbul: Sosyal Yayinlar, 1996), 519-522.

72 Aydın, "Süreç (Proses) Felsefesi Işı̆̆ında Tanrı-Âlem İlişkisi," 81.

73 Abū 'Alī Ḥusayn ibn 'Abd Allāh ibn 'Alī Ibn Sīnā, Kitâbu'ş-Şifâ: Metafizik II (alIläbiyyāt) (ed. with Turkish translation by Ekrem Demirli and Ömer Türker; Istanbul: Litera Yayınc1lik, 2005), 105.

74 Al-Ghazālī, Filozoflarm Tutarsızh̆̆ $ı$, 225.

75 Abū 1-Walīd Ibn Rushd al-Ḥafîd Muhammad ibn Aḥmad al-Qurțubī, Tutarsızlığın Tutarsızh̆̆ $\imath$ (Tabāfut al-Tabāfut) (translated into Turkish by Kemal Iş1k and Mehmet Dağ; Samsun: Ondokuz Mayıs Üniversitesi Yayınları, 1986), 253. Also see Mahmut Kaya, "Gazzâlî Filozofları Tekfir Etmekte Haklı miydı?," in 900. Vefât Yılında İmâm Gazzâlî: Milletlerarası Tartışmalı İlmî Toplantı-07-09 Ekim 2011 İstanbul (Istanbul: Marmara Üniversitesi İlâhiyat Fakültesi Vakfı Yayınları, 2012), 48.

76 Ibn Rushd, Felsefe-Din Ilişkileri (= Fașl al-maqāl and al-Kashf 'an minhāj aladilla) (translated into Turkish with an introduction by Süleyman Uludağ; Istanbul: Dergâh Yayınları, 2004), 134-135; id., Tutarsızlı̆̆ın Tutarsızlı̆̆ı, 257. Averroes' quotation from the Qur'ān about the limitlessness of the knowledge of God 
knowledge seems to resolve this problem. Because God is not included within any category of knowledge, his is a universal knowledge that includes particulars. Therefore, divine science never changes.

The absolute perfection and transcendence of God can also limit His knowledge. Ash'arī kalām scholars defend this position, asserting that God has such absolute perfection that He does not need to follow any wisdom or rule (example) in His acts of creation. Such an approach sentences the knowledge of God to total non-existence. Even man acts pursuant to knowledge and rules. This philosophy causes Averroes to accuse the Ash'arī scholars (especially al-Ghazālī) for considering "God as an eternal man, and man as a mortal God". 77

With few exceptions, the theological approaches of mainstream Judaism $^{78}$, Christianity, ${ }^{79}$ and Islam ${ }^{80}$ accept the temporally and spatially omniscient character of God and do not restrict Him. ${ }^{81}$ However, this view inevitably raises certain issues regarding the abolition of human freedom and the tyranny of God. Within the intellectual tradition of tzimtzum cosmology, the doctrine of kenosis and process philosophy seek to resolve these problems.

Unlike traditional Judeo-Christian conceptions of God, kenosis ontologically limits God, restricting several of His attributes, including potency and, especially, knowledge. This point emphasizes the parallelism between knowledge and potency, the relation between which

is relevant here: "Should He not know - He that created?" (Q 67:14).

77 Ibn Rushd, Tutarsızlığın Tutarsızh $\breve{g} ı, 257$.

78 "Declaring the end from the beginning, and from ancient times things which have not been done, saying, 'My purpose will be established, and I will accomplish all My good pleasure"" (Isaiah 46:10). "Behold, the former things have come to pass ..." (Isaiah 42:9).

79 "Says the Lord, Who makes these things known from long ago" (Acts 15:18). "And there is no creature hidden from His sight, but all things are open and laid bare to the eyes of Him with whom we have to do" (Hebrews 4:13).

80 "Nor is there aught of the unseen, in heaven or earth, but is (recorded) in a clear record." (Q 27:75). "With Him are the keys of the unseen, the treasures that none knoweth but He. He knoweth whatever there is on the earth and in the sea. Not a leaf doth fall but with His knowledge: there is not a grain in the darkness (or depths) of the earth, nor anything fresh or dry (green or withered), but is (inscribed) in a record clear (to those who can read)" (Q 6:59).

81 For further discussions, see Tamar Rudavsky (ed.), Divine Omniscience and Omnipotence in Medieval Philosophy: Islamic Jewish and Christian Perspectives (Dordrecht: Springer Science + Business Media, 1985). 
obstructs the free will of man. According to John Lucas (1879-1934), although God has the potency to realize everything He knows, He does not do so. Instead, God limits His infallible knowledge and potency to render man a free agent. This is not an imposed restriction, but a voluntary self-limitation. ${ }^{82}$ Anthony Kenny considers the views of Lucas inconsistent. According to Kenny, if the limitation of God's knowledge is a voluntary restriction, then God's knowledge is logically possible but unnecessary. Therefore, God, who allegedly knows all, reduces His knowledge to human knowledge for the sake of freeing man..$^{83}$

For Kenny, $16^{\text {th }}$ century Jesuit philosophers Francesco Suarez (15481617) and Luis de Molina (1535-1600) better reconcile divine foreknowledge and human freedom. Molina treats the coexistence of divine knowledge and human freedom as a counterfactual condition that occurs in different ways under different circumstances. Molina suggests that God knows what any possible creature will freely do under all possible circumstances. ${ }^{84}$ In addition, he makes a distinction between the personal knowledge and free knowledge of God and, like Leibniz, distinguishes between the possible beings, produced by and, therefore, God's potential knowledge of these two types.

The arguments made by process philosophy about divine knowledge, which were primarily developed by Whitehead and Hartshorne, are also problematic. A dualist conceptualization of God proposes two types of knowledge that necessarily differ from one another. Nonetheless, there are difficulties in reconciling these apparently paradoxical types of knowledge.

According to Whitehead, God knows all because of His primordial nature. However, this omniscience differs from that of the God of classic theism who knows the past, present and future. In the statement "God knows all," "all" refers to facts that are either possible or actual. Through His omniscience, God knows the actual as actual and the possible as possible. Therefore, God cannot know possibilities yet to be actualized. ${ }^{85}$ Because all possibilities are yet to be actualized, "God

\footnotetext{
82 Anthony Kenny, The God of the Philosophers (Oxford: Clarendon Press, 1979), 60.

83 Ibid., 61-62.

84 Ibid., 62.

85 Lewis S. Ford, "Can Whitehead's God Be Rescued from Process Theism," in James Franklin Harris (ed.), Logic, God and Metaphysics (Dordrecht: Springer Netherlands, 1982), 35; Sia, God in Process Thought, 57.
} 
cannot know the future." For God, the future is "a field of possibilities and probabilities determined one way or another." ${ }^{\prime \prime 6}$ suggesting a divine nature whose limited knowledge makes God almost human; even a man can know the actual as actual and the possible as possible. Indeed, in a determinist universe, man, like Laplace's demon, can almost precisely know certain things. Thereupon, man, who is created by or coexists with God, knows more than God. Consequently, man becomes equal or superior to God. This approach is criticized by alGhazāli in his discussion of the God of emanation theory: "The creatures of God are valued above God" ${ }^{187}$ and "God becomes dead, unaware of what is going on in the universe. ${ }^{\prime 88}$ Because of God's consequent nature, He actualizes Himself in the process of creation and does not know even His own essence. However, in the peripatetic tradition, God at least contemplates and knows His own personality.

Iqbal's position in this debate was described above. Indeed, Iqbal justifies his position in a more comprehensive manner than Whitehead:

If history is regarded merely as a gradually revealed photo of a predetermined order of events, then there is no room in it for novelty and initiation. Consequently, we can attach no meaning to the word 'creation,' which has a meaning for us only in view of our own capacity for original action. The truth is that the whole theological controversy relating to predestination is due to pure speculation with no eye on the spontaneity of life, which is a fact of actual experience. ${ }^{89}$

As this passage indicates, Iqbal, like other panentheist thinkers, restricts the knowledge of God to allow free human action. Iqbal also intends to set nature free, allowing the universe dynamism and saving it from the monopoly of determinism. As Aydin states, Iqbal is neither panentheist nor determinist. ${ }^{90}$ More precisely, he supports neither extreme imminence nor extreme transcendence.

Iqbal seeks a solution to the problem of evil, which he articulates as follows: "How can the universal potency and benevolence of Allah reconcile with the terrible and abundant malignity and evil in the universe?"1 One way to solve the problem is to restrict God and absolve

\footnotetext{
86 Aydın, "Süreç (Proses) Felsefesi Ișığında Tanrı-Âlem İlişkisi," 83.

87 Al-Ghazālī, Filozoflarm Tutarsızlı̆̆ı, 107.

88 Ibid., 72.

89 İkbal, ibid., 112.

90 Aydın, "Muhammed İkbal'in Din Felsefesinde 'Ulûhiyet' Kavramı," 208.

91 İkbal, ibid., 114. Because our main concern is not how Iqbal sees the problem of
} 
Him of any responsibility, as the concepts of tzimtzum and kenosis do, to provide both nature and man with autonomy. Allah provided man with free will ${ }^{92}$ because of His confidence that man would strive in this growing and expanding universe and finally overcome evil. ${ }^{93}$ Thus, Iqbal, by limiting the knowledge and potency of God, makes man, not God, assume the cosmic risk ${ }^{94}$ and, as an ignorant being, according to the Qur'ān, solve the problem of evil.

God's knowledge of variable human actions does not cause Him to change. ${ }^{95}$ It is impossible that the "omniscience of God requires Him to do all He knows." This proposition is based on the following deduction by Aquinas: "Whatever God knows should exist, since even whatever we know has to exist. The knowledge of God is more precise than ours." ${ }^{\prime 6}$ However, there is no such obligation. First, it is wrong to establish an analogy between God and man or to expect all divine knowledge to be actualized. Even some theoretical human knowledge has, at least for now, no corresponding manifestation in reality. Moreover, in addition to knowledge, God has many other names or attributes, including love, mercy, reassurance, patience, forgiveness and

evil, this discussion is beyond the scope of this paper. For the problem of evil in Iqbal, see Mevlüt Albayrak, "İkbal'de Tanrı'nın Kudreti ve Kötülük Problemi," Tasavvuf: Ilmî ve Akademik Araştırma Dergisi 3/7 (2001), 185-193; Ruhattin Yazoğlu, "Süreç Teolojisinde Kötülük Sorunu," EKEV Akademi Dergisi - Sosyal Bilimler-10/29 (2006), 135-144.

92 İkbal, ibid., 120.

93 İkbal, ibid., 121.

94 "We did indeed offer the Trust to the Heavens and the Earth and the Mountains; but they refused to undertake it, being afraid thereof: but man undertook it; - He was indeed unjust and foolish." (Q 33:72).

95 Hanifi Özcan, "Bilgi-Obje İlişkisi Açısından İnsan Hürriyeti," Dokuz Eylül Üniversitesi İlabiyat Fakültesi Dergisi 5 (1989), 281.

96 Anthony Kenny, “Tanri'nın ‘Önceden Bilme'si ve İnsan Hürriyeti ( = Divine Foreknowledge and Human Freedom", in Anthony Kenny [ed.], Aquinas: A Collection of Critical Essays, [Notre Dame: University of Notre Dame Press, 1969])" (translated into Turkish by Hanifi Özcan), Dokuz Eylül Üniversitesi İlabiyat Fakültesi Dergisi 6 (1989), 627. Interestingly, Aquinas contradicts his own tradition by stating that God does not know the "forthcoming" or the "probable," which restricts Him. This is so because the forthcoming and probable are not actually present. However, according to Aquinas, God knows even the existing particulars. In more technical terms, knowledge is subject to the known. This logic is clearly circular (See Kenny, ibid:; Muhammet Tarakçı, St. Thomas Aquinas [Istanbul: İz Yayınc1lik, 2006], 53). 
guidance. Because God simultaneously possesses all these attributes, His knowledge should comply with them. Otherwise, if God were to do everything that He knew, His other attributes would be meaningless and God would become a self-contradictory tyrant who performs unwise deeds.

In the modern era, theologian and biochemist Arthur Peacocke (1924-2006) and pure physics and theology scholar John Polkinghorne (b. 1930) are among those who consider the limitation of God's knowledge and potency necessary to establish a relationship between the natural sciences and divine activity. Peacocke refers to Heisenberg's principle of uncertainty, remarking that God may not know certain unpredictable probabilities about the universe. According to Peacocke, some subatomic particles, non-linear structures and dynamic macroscopic systems are unknown to us; the same may also be true for God. This obscurity is not a logical obligation but arises from the essential characteristics of such structures. Hence, neither man nor God entirely knows them. According to Peacocke, also a panentheistic philosopher, creation is a process. Peacocke also believes that God renounced His potency to create a freely becoming and conscious man. ${ }^{97}$

John Polkinghorne defends a similar position. For him, instead of maintaining a distinction between creator and creature, God introduces pure knowledge into the universe without adding energy. The universe remains in a state that requires energy and epistemic causality. ${ }^{98}$

\section{Conclusion}

The essentially perfect, omniscient, and omnipotent God of classical theism is subject to several philosophical and theological questions and problems. Classical theology proposes the perfection of God because perfection provides God with infinite knowledge and potency, determining nature and restricting the freedom of man. However, restricting God to allow the autonomy of nature and freedom of man also creates problems. Classical theism, for example, renders God absolute and

97 Arthur Peacocke, Theology for a Scientific Age: Being and Becoming - Natural, Divine, and Human (Minneapolis, MN: Fortress Press, 1993), 122-123.

98 Polkinghorne, Faith, Science \& Understanding, 124. Polkinghorne's conception of the relation between God and nature should be treated in a different study. He conducts the discussion in terms of quantum philosophy. Therefore, basic knowledge about quantum physics is needed to properly comprehend the subject. 
man limited by God's will. Tzimtzum and process philosophy, however, limit God's power over nature and man and thus reduce and restrict Him. Although it is assumed that God voluntarily limits Himself, such a restriction is ascribed to God by scholars.

Kenosis addresses problems arising from Christian theology's claims about the nature of Jesus. In Islam, Muhammad is considered a man, and there is therefore no debate about his nature. Hence, a kenotic approach is irrelevant in Islamic thought. This is not, however, to say that there is no problem in Islamic thought regarding divine knowledge and potency.

The virtual humanization of God and establishment of His quasiequality with man by freeing Him from the siege of divine knowledge is an attempt to show that man is free in his actions and that nature has dynamism. This strategy resolves several human-based problems. Nevertheless, can a being who ontologically and epistemologically reduces Himself, rendering Himself ordinary to free man, and who is called God because He possesses attributes humans do not, remain God if He, albeit voluntarily, relinquishes such attributes?

Unless God knows the future and can change what He knows, what is the purpose of praying to and worshipping Him? If God is empty or limited, the laws of nature can be explained without God and man becomes merely a mortal being. If this is so, then human virtues have no meaning or value except in this world.

Today, approaches proposing the self-limitation of God are still debated, especially in the natural sciences, allowing the problematic of this study to be discussed more specifically in the context of thinkers such as Moltman, Wanstone, Polkinghorne, and Peacocke. The problems resolved and generated by these approaches, which appear to be a different form of determinism, should also be discussed.

These debates seek to justify the relation between God, nature and man; indeed, they ensure a dialectic of ideas and an intellectual productivity. Due to the dialectic nature of this issue, the problem may remain as unresolved in the future as it is today. 


\section{REFERENCES}

Albayrak, Mevlüt, “íkbal'de Tanrı'nın Kudreti ve Kötülük Problemi,” Tasavvuf: Ilmî ve Akademik Arasttırma Dergisi 3/7 (2001), 185-193.

"Muhammed İkbal'in Din Felsefesinde Alfred North Whitehead'in Etkisi," Dinî Araştırmalar 4/11 (2001), 35-65.

Alpyağıl, Recep (ed.), Gelen-eksel ve Çağdas Metinlerle Din Felsefesine Dair Okumalar 1 (Istanbul: İz Yayınc1lık, 2011).

Arıcan, M. Kazım, Panteizm, Ateizm ve Panenteizm Bağlamında Spinoza'nın Tann Anlayışı (Istanbul: İz Yayıncilık, 2004).

Aristotle, Metafizik (translated into Turkish by Ahmet Arslan; Istanbul: Sosyal Yayinlar, 1996).

Aydın, Mehmet S., Din Felsefesi (10 ${ }^{\text {th }}$ edn., Izmir: İzmir İlâhiyat Fakültesi Vakfı Yayinlar1, 2002).

"Muhammed İkbal'in Din Felsefesinde 'Ulûhiyet' Kavram1," Ankara Üniversitesi Illâhiyat Fakültesi İslâm İlimleri Enstitüsü Dergisi 4 (1980), 199-209.

"Süreç (Proses) Felsefesi Işığında Tanri-Âlem İlişkisi," in his Âlemden Allab'a (Istanbul: Ufuk Kitapları, 2001), 35-108.

Carmody, J. M., "Kenosis," in Thomas Carson and Joann Cerrito (ed.), New Catholic Encyclopedia, Second Edition (USA: Thomson Gale, 2003).

Cobb, Jr., John B. and Griffin, David R., Süreç Teolojisi (translated into Turkish by Tuncay İmamoğlu and Ruhattin Yazoğlu; Istanbul: İz Yayıncılık, 2006).

Creel, Richard E., "Immutability and Impassibility," in Charles Taliaferro, Paul Draper, and Philip L. Quinn (eds.), A Companion to Philosophy of Religion ( $2^{\text {nd }}$ edn., Malden, MA: Wiley-Blackwell, 2010), 322-328.

http://dx.doi.org/10.1002/9781444320152.ch38

Crisp, Oliver D., Divinity and Humanity: The Incarnation Reconsidered (Cambridge: Cambridge University Press, 2007). http://dx.doi.org/10.1017/CBO9780511805332

Dan, Joseph, Kabbalab: A Very Short Introduction (New York, NY: Oxford University Press, 2006).

Dodds, Michael J., The Unchanging God of Love: Thomas Aquinas and Contemporary Theology on Divine Immutability ( $2^{\text {nd }}$ edn., Washington, D.C.: The Catholic University of America Press, 2008).

Doncel, S. J., Manuel G., "The Kenosis of the Creator and of the Created CoCreator," Zygon 39/4 (2004), 791-800. http://dx.doi.org/10.1111/j.1467-9744.2004.00619.x

Eco, Umberto, Yorum ve Aşrm Yorum (4 ${ }^{\text {th }}$ edn., translated into Turkish by Kemal Atakay; Istanbul: Can Yayınları, 2008).

Edwards, Rem B., "God and Process," in James Franklin Harris (ed.), Logic, God and Metaphysics (Dordrecht: Springer Netherlands, 1982), 45-57. 
Erdoğan, İsmail, “Tanrı'nın Değişmezliği Problemi," Uludă̆ Üniversitesi Ilahiyat Fakültesi Dergisi 13/1 (2004), 39-52.

Evans, C. Stephen, "Introduction: Understanding Jesus the Christ as Human and Divine," in C. Stephen Evans (ed.), Exploring Kenotic Christology (The Self-Emptying of God) (Oxford \& New York, NY: Oxford University Press, 2006), 1-24.

Ford, Lewis S., "Can Whitehead's God Be Rescued from Process Theism," in James Franklin Harris (ed.), Logic, God and Metaphysics (Dordrecht: Springer Netherlands, 1982), 19-39.

al-Ghazālī, Abū Hāmid Muḥammad ibn Muḥammad, Filozoflarnn Tutarsızlı̆̆ı (Tahäfut al-falāsifa) (ed. with Turkish translation by Mahmut Kaya and Hüseyin Sarığlu; Istanbul: Klasik Yayınları, 2005).

Itikadda Orta Yol (al-Iqtișād fi l-i`tiqād) (ed. with Turkish translation by Osman Demir; Istanbul: Klasik Yayınlar1, 2012).

Giller, Pinchas, Reading the Zohar: The Sacred Text of the Kabbalab (New York, NY: Oxford University Press, 2001).

Hartshorne, Charles, A Natural Theology for Our Time (6 ${ }^{\text {th }}$ edn., La Salle, III: Open Court, 1989).

Omnipotence and Other Theological Mistakes (Albany, NY: State University of New York Press, 1984).

Ibn Rushd, Abū l-Walīd Ibn Rushd al-Hafīd Muhammad ibn Ahmad alQurțubī, Felsefe-Din İlişkileri (= Fașl al-maqāl and al-Kashf 'an minhāj al-adilla) (translated into Turkish with an introduction by Süleyman Uludağ; Istanbul: Dergâh Yayınları, 2004).

Tutarsızlı̆̆n Tutarsızlı̆̆ı (Tahāfut al-Tahāfut) (translated into Turkish by Kemal Işık and Mehmet Dağ; Samsun: Ondokuz Mayıs Üniversitesi Yayınları, 1986).

Ibn Sīnā, Abū 'Alī Husayn ibn 'Abd Allāh ibn 'Alī, Kitâbu'ş-Şifâ: Metafizik II (al-Ilähiyyāt) (ed. with Turkish translation by Ekrem Demirli and Ömer Türker; Istanbul: Litera Yayıncılık, 2005).

İkbal, Muhammed (= Muhammad Iqbal), İslâm'da Dinî Düşüncenin Yeniden Doğuşu (translated into Turkish by N. Ahmet Asrar; Istanbul: Birleşik Yayıncilık, n.d.).

Kaya, Mahmut, "Gazzâlî Filozofları Tekfir Etmekte Haklı mıydı?," in 900. Vefât Yılında İmâm Gazzâlî: Milletlerarası Tartışmalı İmî Toplantı-07-09 Ekim 2011 İstanbul (Istanbul: Marmara Üniversitesi İlâhiyat Fakültesi Vakf1 Yayınları, 2012), 43-51.

Kenny, Anthony, The God of the Philosophers (Oxford: Clarendon Press, 1979).

“Tanri'nın 'Önceden Bilme'si ve İnsan Hürriyeti,” ( = Divine Foreknowledge and Human Freedom", in Anthony Kenny [ed.], Aquinas: A Collection of Critical Essays, [Notre Dame: University of Notre 
Dame Press, 1969])" (translated into Turkish by Hanifi Özcan), Dokuz Eylül Üniversitesi Illabiyat Fakültesi Dergisi 6 (1989), 625-638.

Kurt, Ali Osman, Ultra-Ortodoks Yabudiler: Hasidiler ve Mitnagedler (Sivas: Asitan Yayınları, 2011).

Laitman, Rav Michael, Basic Concepts in Kabbalab: Expanding Your Inner Vision (Toronto, Ont.: Laitman Kabbalah Publishers, 2006).

Le Poidevin, Robin, "Kenosis, Necessity and Incarnation," The HeythropJournal 54/2 (2013), 214-227.

http://dx.doi.org/10.1111/j.1468-2265.2012.00796.x

Mavrodes, George I., "Omniscience," in Charles Taliaferro, Paul Draper, and Philip L. Quinn (eds.), A Companion to Philosophy of Religion ( $2^{\text {nd }}$ edn., Malden, MA: Wiley-Blackwell, 2010), 251-257.

http://dx.doi.org/10.1002/9781444320152.ch28

McClain, Alva J., "The Doctrine of the Kenosis in Philippians 2:5-8," The Master's Seminary Journal9/1 (1998), 85-96.

Moltmann, Jürgen, God in Creation: An Ecological Doctrine of Creation (The Gifford Lectures 1984-1985) (London: SCM Press, 1985).

Monserrat, Javier, "Kenosis: Towards a New Theology of Science," Pensamiento: Revista de investigación e Información filosófica 63/238 (2007), 637-658.

Oliver, Simon, "Trinity, Motion and Creation ex Nihilo," in David B. Burrell, Carlo Cogliati, Janet M. Soskice, and William R. Stoeger (eds.), Creation and the God of Abraham (Cambridge: Cambridge University Press, 2010), 133-151. http://dx.doi.org/10.1017/CBO9780511778063.011

Ormsby, Eric Lee, İslam Düşüncesinde 'Illahi Adalet' Sorunu (Teodise) [= Theodicy in Islamic Thought: The Dispute Over Al-Ghazali's Best of All Possible] (translated into Turkish by Metin Özdemir; Ankara: Kitâbiyât, 2001).

Özcan, Hanifi, "Bilgi-Obje İlişkisi Açısından İnsan Hürriyeti," Dokuz Eylül Üniversitesi İlabiyat Fakültesi Dergisi 5 (1989), 263-286.

Özdemir, Metin, Allab'in Bilgisinin Ezelîliği ve İnsan Hürriyeti (Istanbul: İz Yayıncilik, 2003).

Peacocke, Arthur, Theology for a Scientific Age: Being and Becoming - Natural, Divine, and Human (Minneapolis, MN: Fortress Press, 1993).

Plantinga, Alvin, Does God Have a Nature? (Milwaukee, WI: Marquette University Press, 1980).

Polkinghorne, John, Faith, Science \& Understanding (New Haven, CT: Yale University Press, 2000).

Rudavsky, Tamar (ed.), Divine Omniscience and Omnipotence in Medieval Philosophy: Islamic Jewish and Christian Perspectives (Dordrecht: Springer Science + Business Media, 1985).

Russell, Robert John, "Introduction," in Robert John Russell, Nancey Murphy 
and Arthur R. Peacocke (eds.), Chaos and Complexity: Scientific Perspectives on Divine Action (Vatican City State: Vatican Observatory Publications, 1995), 1-31.

Sia, Santiago, God in Process Thought: A Study in Charles Hartshorne's Concept of God (Dordrecht \& Boston: Martinus Nijhoff Publishers, 1985). http://dx.doi.org/10.1007/978-94-009-5069-6

Stump, Eleonore, "Simplicity," in Charles Taliaferro, Paul Draper, and Philip L. Quinn (eds.), A Companion to Philosophy of Religion ( $2^{\text {nd }}$ edn., Malden, MA: Wiley-Blackwell, 2010), 270-277.

http://dx.doi.org/10.1002/9781444320152.ch31

Swinburne, Richard, Tann Var mı? (translated into Turkish by Muhsin Akbaş; Bursa: Arasta Yayınları, 2001).

The Christian God (Oxford: Clarendon Press, 1994).

The Coberence of Theism (revised edn., Oxford: Clarendon Press, 1993).

Tarakçı, Muhammet, St. Thomas Aquinas (Istanbul: İz Yayıncılık, 2006).

Torrance, Alan J., "Creatio ex Nibilo and the Spatio-Temporal Dimensions, with special reference to Jürgen Moltmann and D. C. Williams," in Colin E. Gunton (ed.), The Doctrine of Creation: Essays in Dogmatics, History and Philosophy (London \& New York, NY: T \& T Clark, 2004), 83-103.

Ward, Keith, Rational Theology and the Creativity of God (Oxford: Basil Blackwell, 1985).

Ward, Wayne E., "The Person of Christ: The Kenotic Theory," in Carl F. H. Henry (ed.), Basic Christian Doctrines (Dallas: C Bible Society, 2002), 131-138.

Webb, Mark Owen, "Perfect Being Theology," in Charles Taliaferro, Paul Draper, and Philip L. Quinn (eds.), A Companion to Philosophy of Religion ( $2^{\text {nd }}$ edn., Malden, MA: Wiley-Blackwell, 2010), 227-234. http://dx.doi.org/10.1002/9781444320152.ch25

Whitehead, Alfred North, Process and Reality: An Essay in Cosmology (New York: The Free Press, 1978).

Science and the Modern World (New York, NY: New American Library, 1948).

Wierenga, Edward R., The Nature of God: An Inquiry into Divine Attributes (Ithaca, NY: Cornell University Press, 1989).

Wolfson, Harry Austryn, The Philosophy of the Kalam (Cambridge, Mass. \& London: Harvard University Press, 1976).

Yazoğlu, Ruhattin, "Süreç Teolojisinde Kötülük Sorunu," EKEV Akademi Dergisi - Sosyal Bilimler - 10/29 (2006), 135-144. 